\title{
PERAN PERNYATAAN ORIENTASI TUJUAN KINERJA DAN PERNYATAAN ORIENTASI TUJUAN PEMBELAJARAN TERHADAP KEMAMPUAN MAHASISWA
}

\section{ROLE OF PERFORMANCE PURPOSE ORIENTATION STATEMENT AND ORIENTATION LEARNING OBJECTIVES STATEMENT TOWARDS STUDENT ABILITY}

\author{
Ahmad Muzaki', Diyah Probowulan², Achmad Syahfrudin ${ }^{3}$ \\ Universitas Muhammadiyah Jember ${ }^{1,2,3}$ \\ $\underline{\text { Ahmadmuzaki22@gmail.com }}{ }^{1}$
}

\begin{abstract}
ABSCTRACT
Objective orientation is a mental framework as individuals give an impression and respond to situations or events that they face. Typically there are two kinds of goal orientation, namely orientation of performance goals (performance orientation) and orientation of learning goals (learning goal orientation). The phenomenon that there are still students who are extension or extension of time in doing the Final Project are all caused by the ability possessed by the individual. There are three factors that underlie the ability; self-efficacy, goals and performance. The researcher followed up the existence problems in the 2015 Accounting Study Program with four samples of Higher Education in Jember Regency, there were 82 respondents to answer the questionnaire given. Therefore an analytical tool is needed to determine the abilities possessed by students of the Accounting Study Program in Jember Regency. In this study researchers will test performance goal orientation statements (state performance goal orientation) and statement of learning goal orientation (state learning goal orientation) on self-efficacy (self-efficacy), goals (goals) and performance (performance) that each individual has.
\end{abstract}

Keywords: Goal Orientation, State Goal Orientation Learning, State Performance Goal Orientation, Self-Efficacy, Goals and Performance.

\begin{abstract}
ABSTRAK
Orientasi obyektif adalah kerangka kerja mental ketika individu memberi kesan dan menanggapi situasi atau peristiwa yang mereka hadapi. Biasanya ada dua macam orientasi tujuan, yaitu orientasi tujuan kinerja (orientasi kinerja) dan orientasi tujuan pembelajaran (orientasi tujuan pembelajaran). Fenomena bahwa masih ada siswa yang merupakan perpanjangan atau perpanjangan waktu dalam mengerjakan Tugas Akhir semuanya disebabkan oleh kemampuan yang dimiliki oleh individu. Ada tiga faktor yang mendasari kemampuan; self-efficacy, tujuan dan kinerja. Peneliti menindaklanjuti masalah yang ada di Program Studi Akuntansi 2015 dengan empat sampel Pendidikan Tinggi di Kabupaten Jember, ada 82 responden untuk menjawab kuesioner yang diberikan. Oleh karena itu diperlukan alat analisis untuk mengetahui kemampuan yang dimiliki oleh mahasiswa Program Studi Akuntansi di Kabupaten Jember. Dalam penelitian ini peneliti akan menguji pernyataan orientasi tujuan kinerja (state performance goal direction) dan pernyataan orientasi tujuan pembelajaran (state
\end{abstract}


learning goal direction) pada self-efficacy (self-efficacy), tujuan (sasaran) dan kinerja (kinerja) yang dimiliki setiap individu telah.

Kata Kunci: Orientasi Sasaran, Pembelajaran Orientasi Sasaran Negara, Orientasi Sasaran Kinerja Negara, Self-Efficacy, Sasaran dan Kinerja.

\section{PENDAHULUAN}

Setiap individu dipastikan memiliki kebutuhan-kebutuhan yang hendak dipenuhi. Dalam memenuhi suatu kebutuhan-kebutuhan tersebut, setiap individu mempunyai sikap dan perilaku yang berbeda antara satu sama lain. Sebaliknya, apabila terdapat suatu kebutuhan yang belum terpenuhi, juga akan berdampak pada perubahan sikap dan perilakunya. Hal tersebut menunjukkan bahwa kebutuhan mempunyai pesan yang sangat penting dan menentukan tingkah laku manusia. Tingkah laku manusia timbul karena danya suatu kebutuhan dan tingkah laku manusia tersebut mengarah pada pencapaian tujuan yang dapat memenuhi atau memuaskan kebutuhan itu sendiri (Desmita 2010).

Perguruan tinggi saat ini merupakan jenjang pendidikan tertinggi dalam pendidikan nasional di Indonesia yang diharapkan mampu menciptakan pikiran manusia yang berkualitas dan berintelektual sehingga dapat merubah masa depan bangsa dan negara yang lebih baik. Saat ini bidang akuntansi merupakan salah satu bidang yang menjadi perhatian bagi masyarakat. Faktor penting yang dapat menunjang kesuksesan mahasiswa dalam memperoleh prestasinya berasal dari personal individunya. Keyakinan, niat dan kesungguhan merupakan motivasi yang baik dalam mencapai suatu tujuan.

Orientasi tujuan merupakan suatu preferensi yang tujuan dalam pencapaian situasi, telah menjadi salah satu topik yang paling penting dalam proses pendidikan, psikologis dan literatur penelitian organisasi (Payne, dkk 2007). Orientasi tujuan secara garis besar memberikan kekuatan mental bagi seseorang untuk digunakan sebagai manafsirkan dan menggapai pencapaian dan kegagalan situasi (Dweck \& Leggett, 1988) dan perbedaan individu yang berguna untuk membangun pemahaman terhadap pembelajaran, pelatihan dan hasil kinerja (Zweig \& Webster, 2004). Orientasi tujuan ditemukan berdampak pada beberapa proses motivasional kunci, antara lain: upaya dari individu-individu selama menghasilkan tujuan kinerja (performance), kemampuan individu (self-efficacy), tujuan individu (goals) dan beberapa revisi tujuan individu ketika menghadapi kegagalan.

Peneliti menemukan fenomena bahwa terdapat mahasiswa yang ekstensi skripsi disetiap tahunnya. Ekstensi skripsi yaitu mahasiswa yang mengambil perpanjangan waktu semester berikutnya untuk menyelesaikan tugas skripsi. Feneomena ini didapatkan dari hasil wawancara terhadap beberapa responden, dimana responden tersebut mengalami hambatan yang berbedabeda. Seperti, malas, sulitnya mendapatkan data, objek penelitian yang tidak koperatif, manajemen waktu yang diatur, sulitnya mencari teori yang sesuai untuk digunakan, sulitnya mendapatkan buku yang akan digunakan, komunikasi yang kurang baik dan kurang intensif terhadap dosen pembimbing dan jurnal yang digunakan kurang sesuai dengan kondisi responden. Teori Penetapan Tujuan

Teori penetapan tujuan merupakan bagian dari teori motivasi 
yang dikemukakan oleh (Edwin Locke, 1978). Teori ini menegaskan bahwa individu dengan tujuan yang lebih baik, spesifik dan menantang kinerjanya akan lebih baik dibandingakan dengan tujuan yang tidak jelas, seperti "melakukan apa uang terbaik dari diri kita", tujuan mudah yang spesifik atau tidak ada tujuan sama sekali.

Orientasi tujuan merupakan suatu mental kerangka sebagaimana individu memberikan kesan dan merespon situasi atau kejadian yang dihadapinya (Dweck \& Legget, 1988). Secara khas ada dua macam orientasi tujuan (goal orientation), yaitu orientasi tujuan kinerja (performance orientation) dan orientasi tujuan pebelajaran (learning goals). Orientasi tujuan dalam mencapai prestasi diklasifikasikan menjadi dua yaitu orientasi tujuan pembelajaran dan orientasi tujuan kinerja (Mustikawati, 2006). Rono (2012) menyatakan teori bahwa terdapat dua buah pola perilaku yang mencerminkan goal orientation yang berbeda. Dua jenis goal orientation tersebut adalah learning goal orientation dan performance goal orientation.

Mahasiswa yang menggunakan metode performance goal orientation lebih cenderung mengejar hasil dari pada proses. Mahasiswa seperti ini menginginkan penilaian yang lebih baik terhadap performanya dan menghindari penilaian negatif dari orang lain. Mahasiswa dengan performance goal orientation ini lebih bertujuan untuk menunjukan keuanggulan, kesanggupan, kecakapan dan kemampuan mereka kepada mahasiswa lainnya. Bagi mereka, sebuah upaya (effort) dipandang secara negatif. Mahasiswa dengan performance goal orientation melihat intelejensi sebagai hal yang menetap, kemudian mereka juga menghindari penilaian yang bersifat negatif dari orang lain, serta mereka lebih termotivasi secara eksternal dan sebuah kesalahan diartikan oleh mahasiswa tersebut sebagai ketidakmampuan, Rono (2012).

Mahasiswa yang menggunakan metode Learning Goal Orientation (LGO) memiliki sebuah tujuan dalam belajar yaitu untuk mempelajari keahlian dan ilmu yang baru. Karakteristik mahasiswa ini adalah memiliki daya tahan ketika dihadapkan pada suatu masalah, ingin mencoba berbagai strategi pemecahan masalah, serta menikmati tantangan. Berkaitan dengan faktor-faktor lain yang mempengaruhi prestasi, Learning Goal Orientation (LGO) dapat memprediksi keberhasilan prestasi akademis lebih baik dibandingkan dengan perkiraan dari kepribadian dan kecerdasan seseorang.

Secara psikologis, ability (kemampuan) terdiri dari kemampuan potensi (IQ) dan kemampuan reality (knowledge + skill), kemampuan adalah segala sesuatu yang dimiliki oleh seseorang yang dipengaruhi dan terbentuk dari pengetahuan dan keterampilan yang dimilikinya (Mangkunegara, 2008:68). Variabel ini diukur dengan menggunakan IPK masing-masing partisipan sebagai indikator.

Self-efficacy mengarah pada keyakinan seseorang terhadap kemampuannya dalam mengatur dan melaksanakan serangkaian tindakan dalam mencapai hasil yang ditetapkan (Bandura, 1997, dalam Pradiantie, 2012). Variabel ini diukur dengan meminta partisipan memberi tingkat keyakinannya (dalam \%) untuk masingmasing tingkatan nilai dari hasil test (UAS), Lee \& Bobko (1994).

Goals (tujuan) merupakan suatu pernyataan tentang keadaan yang ingin dicapai dalam jangka waktu tertentu. Tujuan ini ditetapkan sebagai dasar 
pengakuan untuk menilai pencapaian tujuan tersebut dan juga tujuan digunakan untuk menciptakan proses pengendalian. Variabel ini diukur dengan meminta responden untuk mengindikasikan tujuan atau sasaran nilai tes (UAS) dengan menyatakan harapannya dalam bentuk nilai mutlak 0 sampai 100.

Kinerja (performance) sumber daya manusia merupakan istilah yang berasal dari kata Job Performance atau Actual Performance (prestasi kerja atau prestasi sesungguhnya yang dicapai oleh seseorang). Variabel ini diukur menggunakan nilai yang diperoleh masing-masing responden dalam tes yang dilakukan (UAS). Agar konsisten maka semua skala nilai yang diberikan untuk masing-masing tes (UAS) sama, maka digunakan satu standar penilaian yaitu nilai murni 0 sampai 100 .

Performance/Kinerja. Oleh karena itu State Learning Goal Orientation (SLGO) dan State Performance Goal Orientation (SPGO) akan diuji dengan 3 variabel dependen yang sudah dijelaskan.

Seperti yang dibahas sebelumnya, riset dalam bidang motivasi kerja menduga bahwa orientasi tujuan personal terdapat dampak pada suatu proses pencapaian tujuan. Berdasarkan itu maka individu dengan performance goal orientation yang kuat akan menetapkan tujuan yang kurang menantang dan takut mengalami kegagalan dibanding pada individu yang performance goal orientationnya lemah. Sedangkan pada learning goal orientation yang kuat cenderung suka dengan tantangan dan menetapkan suatu tujuan yang tinggi serta tidak takut dengan kegagalan pencapaian tujuan dibanding dengan learning goal orientation yang lemah.
Penelitian terakhir oleh Philip dan Gully (1997), Vande Walle dkk (1999) dan Chen dkk (2000) menunjukan bahwa learning goal orientation memainkan peran penting dalam proses pencapaian tujuan melalui self-efficacy dimana: individu dengan learning goal orientation kuat cenderung menggambarkan level self-efficacy yang lebih tinggi dalam performance dan lebih menantang tujuan-tujuannya dibanding individu yang learning goal orientationnya lemah. Berbeda dengan temuan learning goal orientation, pada performance goal orientation temuan riset menunjukan bahwa peran performance goal orientation kurang konklusif. Contoh: Philip dan Gully (1997) menemukan bahwa performance goals orientation berhubungan negatif dengan tingkat self-efficacy dan performance goals pada tiap individual, riset lainnya menunjukan bahwa performance goals orientation juga tidak berhubungan dengan self-efficacy dan goal choice (Donovan \& Williams, 1999). Pada meta analysis oleh Beaubien \& Payne (1999) menyebutkan bahwa performance goals orientation sangat tidak konsisten berhubungan dengan self-efficacy. Dengan demikian learning goals orientation sangat jelas berperan didalam proses pencapaian tujuan, sementara peran performance goals orientation individual masih kurang jelas.

Elliot \& Church (1997), Mangos \& Steele-Johnson (2001), Vande Walle, Cron \& Slocum (2001) menduga bahwa, individu-individu meletakkan orientasi tujuan dalam berbagai cara, misalnya individu-individu menyatakan orientasi tujuannya (state goal orientation, SGO) yang berbeda dalam menggapai karakteristik lingkungan yang mereka hadapi. Contoh, riset yang dilakukan Ames dan Archer (1988) dan Butler (1987, 1993) menyatakan bahwa 
state goal orientation individual adalah responsif dan secara parsial ditentukan oleh karakteristik lingkungan kerja.

\section{METODE PENELITIAN Populasi dan Sampel}

Sampel pada peneliti adalah mahasiswa S1 Program Studi Akuntansi angkatan 2015 di Empat Perguruan Tinggi Kabupaten Jember, diantaranya adalah Universitas Jember, Universitas Muhammadiyah Jember, STIE Mandala dan IAIN Jember.

\section{Metode Pengambilan Sampel}

Cara penggambilan sampel pada penilitian ini yaitu dengan menggunakan probability sampling, disebut juga dengan metode pemilihan sampel secara acak (random sampling method,) Indriantoro \& Supomo (2009). Metode ini berupa analisis regresi logistik. Berdasarkan hasil survey pada Perguruan Tinggi di Kabupaten Jember tahun 2019 jumlah sampel sebanyak 82 responden, jumlah tersebut sudah mewakili mahasiswa Prodi Akuntansi di Kabupaten Jember tahun 2015.

Tabel 1. Populasi

\begin{tabular}{llc}
\hline No & Nama Instansi & $\begin{array}{c}\text { Jumlah } \\
\text { Mahasiswa } \\
\text { Tahun 2015 }\end{array}$ \\
\hline 1 & Universitas Jember & 158 mahasiswa \\
\hline 2 & $\begin{array}{l}\text { Universitas } \\
\text { Muhammadiyah } \\
\text { Jember }\end{array}$ & 190 mahasiswa \\
\hline 3 & $\begin{array}{l}\text { STIE Mandala } \\
\text { Jember }\end{array}$ & 59 mahasiswa \\
\hline 4 & IAIN Jember & 55 mahasiswa \\
\hline & Total & $\begin{array}{c}\mathbf{4 6 2} \\
\text { mahasiswa }\end{array}$ \\
\hline
\end{tabular}

\section{Medode Pengumpulan Data}

Teknik Pengumpulan data dalam penelitian ini menguunakan metode survei, penyebaran kuesioner dan dokumentasi.

\section{Uji Analisis Data}

Statistik Deskriptif

Menurut Indriantoro \& Supomo (2009), metode deskriptif merupakan penelitian terhadap populasi atau fenomena tertentu yang diperoleh peneliti dari subjek berupa: individu, organisasi, industri atau dari sudut pandang yang lain. Analisis ini bertujuan untuk memperoleh hasil gambaran mengenai jumlah responden yang mencakup ukuran tendensi sentral seperti rata-rata (mean) dan standar deviasi yang diungkapkan untuk memperjelas deskripsi atau uraian dari responden.

\section{Uji Non-Response Bias}

Pada pengujian non-response bias digunakan dengan tujuan untuk mengetahui adanya kesalahan yang timbul karena subjek sampel yang tidak memberikan respon (non-responden) tehadap pemberian kuesioner, ternyata lebih sesuai dari sampel memberikan respon, sehingga sampel yang diteliti oleh peneliti kurang akurat, (Indriantoro \& Supomo, 2009).

\section{Uji Kualitas Data}

\section{Uji validitas}

Uji validitas dilakukan untuk mengetahui apakah alat ukur yang telah disusun dapat digunakan untuk mengukur apa yang hendak akan diukur secara tepat (Sudarmanto, 2005). Uji coba yang dilakukan sebaiknya dilakukan minimal terhadap 30 orang responden, (Singarimbun, 1989).

\section{Uji reliabilitas}

Uji reliabilitas yaitu uji yang digunakan untuk mengukur kuesioner yang merupakan indikator dari variabel atau kontruk (Ghozali, 2001). Pengukuran dilakukan hanya sekali dan kemudian hasilnya dibandingkan dengan pertanyaan. Suatu variabel dikatakan reliabel jika memberikan nilai cronbach alpha 0,06 (Ghozali, 2001). Sedangkan perhitungan bobot penilaian 
kuesioner bagi hasil kemampuan mahasiswa adalah dengan menggunakan skala Likert yang merupakan metode untuk mengukur sikap dengan menyatakan setuju atau ketidak setujuannya terhadap subjek, objek atau suatu kejadian tertentu (Indriantoro \& Supomo, 2009).

Skala Likert berisi empat tingkat jawaban dengan pilihan sebagai berikut

Tabel 2. Skala Likert

\begin{tabular}{|c|c|}
\hline Tingkat Setuju & Skor \\
\hline $\begin{array}{ll}\text { Sangat } & \text { Tidak }\end{array}$ & 1 \\
\hline Setuju (STS) & 2 \\
\hline Tidak Setuju (TS) & 3 \\
\hline Setuju (S) & 4 \\
\hline Sangat Setuju (SS) & \\
\hline
\end{tabular}

\section{Uji Multikolinearitas}

Uji multikolinearitas merupakan pengujian yang bertujuan untuk menguji apakah model regresi berkorelasi dengan variabel independen (bebas). Uji multikolinearitas dapat dilihat dari nilai toleransi dan nilai VIF (Variance Iinflation Factor). Apabila nilai toleransi tidak $<10 \%$ dan nilai VIF , 10 , maka terjadi multikolinearitas antara variabel bebas dalam model regresi ini.

\section{Uji Asumsi Fit Model}

\section{Uji Hosmer and Lemeshow}

Kelayakan model regresi dinilai menggunakan Hosmer and Lemeshow's Goodness of Fit Test. Hosmer and Lemeshow's Goodness of Fit Test menguji data empiris cocok atau sesuai dengan model (tidak ada perubahan antara model dengan data yang sehingga model dapat dikatakan fit). Jika nilai statistic Hosmer and Lemeshow's Goodness of Fit Test sama dengan atau kurang dari 0,05, maka ada perbedaan signifikan antara model dengan nilai observasinya sehingga Goodness fit model tidak baik karena model tidak dapat memprediksi nilai observasinya. Jika nilai statistik Hosmer and Lemeshow's Goodness of Fit Test lebih besar dari 0,05, maka model mampu memprediksi nilai observasinya atau dapat dikatakan model dapat diterima karena cocok dengan data observasinya (Ghozali, 2009).

\section{Uji Likelihood Fit Model}

Uji Likelihood Fit Model merupakan regresi logistik dengan membandingkan nilai hasil penelitian dari variabel respon menjadi nilai prediksi dilihat dari model dengan atau tanpa variabel pertanyaannya. Dalam Uji Likelihood Fit Model jika dilihat dari hasil akhir < dari hasil awal, maka Uji Likelihood Fit Model ini dinyatakan baik dan layak menjadi asumsi fit model.

\section{Analisis Regresi Logistik}

Analisis yang digunakan unntuk menguji penelitian ini adalah analisis regresi logistik karena pengunjian ini merupakan suatu metode analisis statistika yang dapat mendeskripsikan hubungan antara peubah respon (dependen variable) yang bersifat kuantitatif memiliki dua kategoriatau lebih dengan satu atau lebih peubah penjelas (independent variable) berskala kategori atau interval.

Metode analisis data dalam penelitian ini menggunakan teknik analisis kuantitatif. Analisis kuantitatif ini dilakukan dengan cara menganalisis suatu permasalahan yang diwujudkan dengan data yang dapat dijelaskan secara kuantitatif. Dalam penelitian ini, analisis kuantitatif dilakukan dengan cara menguantifikasi/menyatakan jumlah satuan dalam angka data-data penelitian sehingga menghasilkan informasi yang dibutuhkan dalam analisis data.

Metode regresi logistik sebenarnya mirip dengan analisis diskriminan, menurut (Ghozali, 2011). Analisis ini ingin menguji apakah terjadinya variabel terikat (dependen) dapat diprediksi dengan variabel bebasnya (independen). Penelitian ini 
menggunakan pendekatan kuantitatif yang merupakan penekanan pada pengujian teori melalui pengukuran variabel penelitian dengan angka dan melakukan analisis data dengan prosedur statistik yang ada.

Model yang digunakan dengan formulasi sebagai berikut (Sumber : Ghozali, 2003) :

$$
\begin{gathered}
\operatorname{Ln}\left(\frac{P}{1-P}\right)=\underset{\text { BP }}{\text { SPGO }} \text { B1 SLGO }+ \text { B2 } \\
\text { SLO }
\end{gathered}
$$

Keterangan :

Ln $(\log$ Natural $) \quad=$ Simbol yang menunjukan probalilitas variabel dependen

B $=$ Koefisien

Regresi

\section{Uji Hipotesis}

\section{Uji Nagalkerke R Square}

Nilai $\mathrm{R}^{2}$ digunakan untuk mengukur tingkat kemampuan model dalam menerangkan variasi independen. Nilai koefisien determinasi adalah antara nol dan satu. Jika nilai $\mathrm{R}^{2}$ yang kecil berarti kemampuan variabelvariabel independen dalam menjelaskan variasi variabel dependen sangat terbatas. Jika nilai yang mendekati satu berarti variabel-variabel independen memberikan hampir semua informasi yang dibutuhkan untuk memprediksi variasi variabel dependen.

\section{Uji Omnimbus Test}

Uji Omnimbus Test merupakan uji secara keseluruhan. Uji Omnimbus Test digunakan untuk menguji hipotesis secara keseluruhan dengan nilai signifikansi terbesar $0(=0)$, dengan df (degress of fridom) atau sebanyak variabel bebas, mengikuti nilai distribusi Chi-Square.

\section{Uji Wald Test}

Menurut teori (Warjono, 2010), dalam regresi logistik uji wald digunakan untuk mengujia ada tidaknya pengaruh dari variabel bebas terhadap variabel terikat secara parsial dengan cara membandingkan nilai ststistik wald dengan nilai pembanding chi square pada derajat bebas $(\mathrm{db})=1$ pada alpha $5 \%$ atau dengan mebandingkan nilai signifikansi (p-value) dengan alpha sebesar 5\% dimana $\mathrm{p}$-value yang lebih kecil dari alpha menunjukan bahwa hipotesis diterima atau terdapat pengaruh yang signifikan dari variabel bebas terhadap variabel terikat secara parsial.

\section{HASIL DAN PEMBAHASAN \\ Uji Analisis Data \\ Statistik Deskriptif}

\begin{tabular}{|c|c|c|c|c|c|c|}
\hline & & $S L G O$ & $S P G O$ & $\begin{array}{c}\text { SELF- } \\
\text { EFFICA } \\
C Y \\
\end{array}$ & GOAL & $\begin{array}{c}\text { PERFOR } \\
\text { MANCE }\end{array}$ \\
\hline \multirow[b]{2}{*}{$\mathbf{N}$} & Valid & 82 & 82 & 82 & 82 & 82 \\
\hline & $\begin{array}{l}\text { Missi } \\
n g\end{array}$ & 0 & 0 & 0 & 0 & 0 \\
\hline \multicolumn{2}{|c|}{ Mean } & 1,23 & 1,37 & 1,44 & 1,40 & 1,44 \\
\hline \multicolumn{2}{|c|}{ Median } & 1,00 & 1,00 & 1,00 & 1,00 & 1,00 \\
\hline \multicolumn{2}{|c|}{ Std. Deviation } &, 425 & ,485 & ,499 &, 493 & ,499 \\
\hline \multicolumn{2}{|c|}{ Variance } &, 180 &, 235 &, 249 &, 243 &, 249 \\
\hline \multicolumn{2}{|c|}{ Minimum } & 1 & 1 & 1 & 1 & 1 \\
\hline \multicolumn{2}{|c|}{ Maximum } & 2 & 2 & 2 & 2 & 2 \\
\hline
\end{tabular}

Tabel 3 Statistik Deskriptif

Tabel output diatas memberikan

informasi tentang $\mathrm{N}$ atau jumlah data yang valid adalah 82 siswa, sedangkan data tang hilang (missing) adalah 0 . Artinya semua data SLGO, SPGO, SelfEfficacy, Goal dan Perforance di proses ke SPSS. Mean menunjukan nilai ratarata. Median menunjukan nilai tengah data yaitu jika data diurutkan dan dibagi menjadi dua sama besar. Standard devisiasi menunjukan dispersi rata-rata dari sampel. Minimum menjunjukan nilai terendah dari hasil jawaban kuesioner. Maximum menunjukan nilai tertinggi dari hasil jawaban kuesioner. Variabel SLGO memiliki mean 3,70 dari 82 responden. Variabel SPGO memiliki mean 2,89 dari 82 responden. Variabel Self-Efficacy memiliki mean 2,83 dari 82 responden. Variabel Goal memiliki mean 2,84 dari 82 responden. Variabel Performance memiliki mean 2,85 dari 82 responden. 
Uji Non-Response Bias (Uji T-test)

Tabel 4. Uji Non-Response Bias

\begin{tabular}{|c|c|c|c|c|c|c|}
\hline & \multicolumn{6}{|c|}{ Test Value $=0$} \\
\hline & \multirow[t]{2}{*}{$\mathrm{t}$} & \multirow[t]{2}{*}{$\mathrm{Df}$} & \multirow[t]{2}{*}{$\begin{array}{l}\text { Sig. } \\
(2- \\
\text { tailed) }\end{array}$} & \multirow[t]{2}{*}{$\begin{array}{l}\text { Mean } \\
\text { Differ } \\
\text { ence }\end{array}$} & \multicolumn{2}{|c|}{$\begin{array}{c}95 \% \\
\text { Confidence } \\
\text { Interval of the } \\
\text { Difference }\end{array}$} \\
\hline & & & & & Lower & Upper \\
\hline SLGO & 26,273 & 81 & , 000 & 1,232 & 1,14 & 1,32 \\
\hline SPGO & 25,251 & 81 & 000 & 1,366 & 1,26 & 1,47 \\
\hline $\begin{array}{l}\text { SELF- } \\
\text { EFFICAC } \\
\text { Y }\end{array}$ & 26,097 & 81 & ,000 & 1,439 & 1,33 & 1,55 \\
\hline GOAL & 25,739 & 81 & ,000 & 1,402 & 1,29 & 1,51 \\
\hline $\begin{array}{l}\text { PERFOR } \\
\text { MANCE }\end{array}$ & 26,097 & 81 & ,000 & 1,439 & 1,33 & 1,55 \\
\hline
\end{tabular}

Berdasarkan tabel One-Sample

Test diatas diketahui nilai $\mathrm{t}$ (t-hitung)

SLGO, SPGO, Self-Efficacy, Goal dan

Performance berturut-turut adalah sebesar 26,273, 25,251, 26,097, 25,739 dan 26,097. Nilai df (degree of freedom) atau derajat kebebasan semua variabel adalah sebesar 81 . Nilai sig. (2-tailed) atau nilai signifikansi dengan uji dua sisi semua variabel adalah sebesar 0,000 .

\section{Uji Kualitas Data}

Uji Validitas

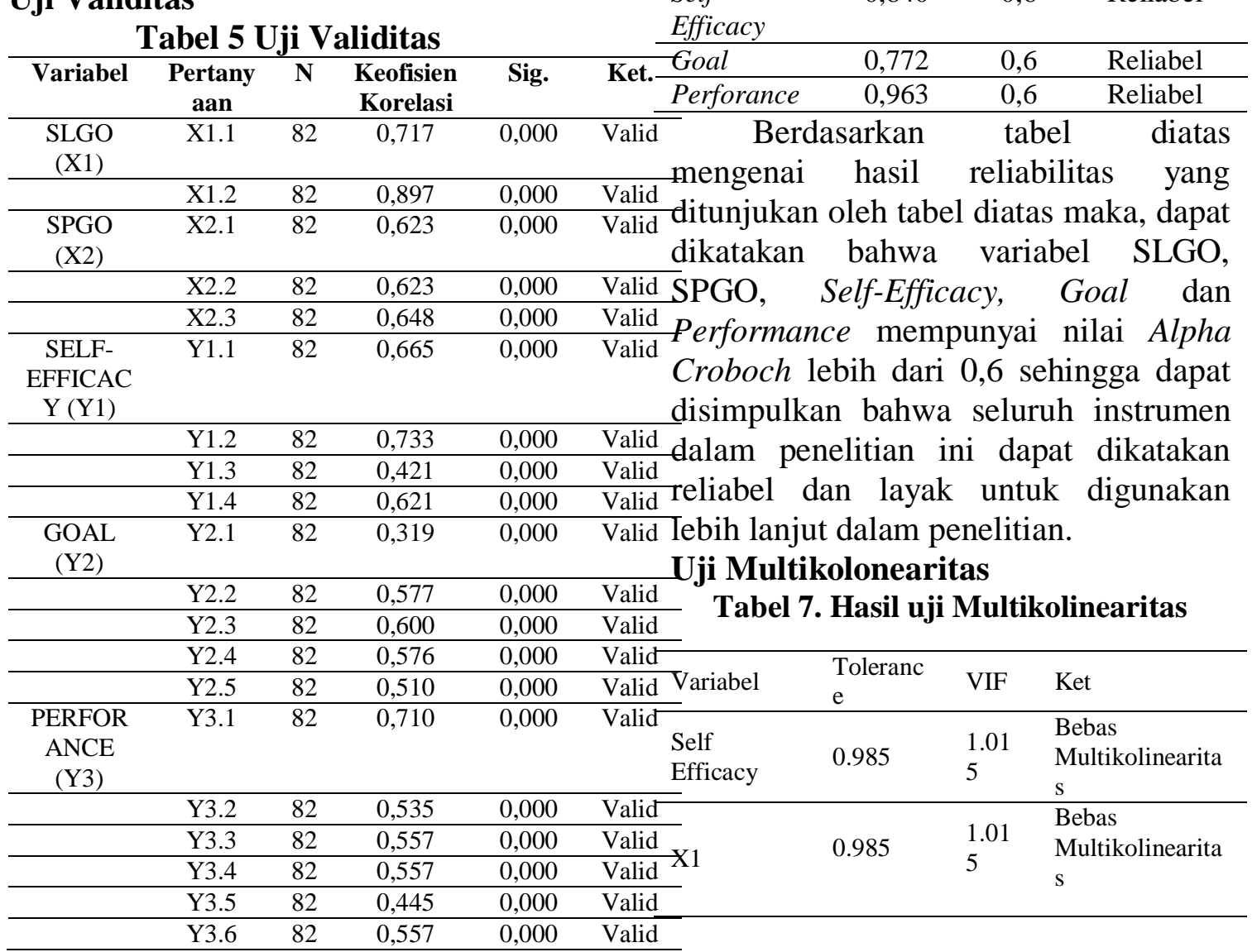

\begin{tabular}{rrrrc}
\hline Y3.7 & 82 & 0,557 & 0,000 & Valid \\
\hline Y3.8 & 82 & 0,421 & 0,000 & Valid \\
\hline Y3.9 & 82 & 0,557 & 0,000 & Valid \\
\hline Y3.10 & 82 & 0,557 & 0,000 & Valid \\
\hline Y3.11 & 82 & 0,535 & 0,000 & Valid \\
\hline Y3.12 & 82 & 0,557 & 0,000 & Valid \\
\hline Y3.13 & 82 & 0,445 & 0,000 & Valid \\
\hline Y3.14 & 82 & 0,557 & 0,000 & Valid \\
\hline Y3.15 & 82 & 0,557 & 0,000 & Valid \\
\hline Berdasarkan & jumlah & sampel &
\end{tabular}

sebanyak 82 responden dengan signifikan $5 \%$ pada tabel 4.3 diatas menunjukan bahwa $r_{\text {tabel }}$ dari setiap variabel SLGO, SPGO, Self-Efficacy, Goal dan Performance lebih besar dari $r_{\text {tabel }}$ 0,216 dengan tingkat signifikan 5\% sehingga dapat disimpulkan bahwa seluruh instrumen pertanyaan yang digunakan penelitian ini adalah valid dan layak untuk diolah.

Uji reliabilitas

Tabel 6. Uji Reliabilitas

\begin{tabular}{lccc}
\hline Variabel & $\begin{array}{c}\text { Alpha } \\
\text { Cronbach }\end{array}$ & Alpa & Keterangan \\
\hline SLGO & 0,885 & 0,6 & Reliabel \\
\hline SPGO & 0,770 & 0,6 & Reliabel \\
\hline $\begin{array}{l}\text { Self- } \\
\text { Efficacy }\end{array}$ & 0,840 & 0,6 & Reliabel \\
\hline Goal & 0,772 & 0,6 & Reliabel \\
\hline Perforance & 0,963 & 0,6 & Reliabel \\
\hline \multicolumn{2}{c}{ Berdasarkan } & tabel & diatas
\end{tabular}

mengenai hasil reliabilitas yang ditunjukan oleh tabel diatas maka, dapat SPGO, Self-Efficacy, Goal dan Croboch lebih dari 0,6 sehingga dapat disimpulkan bahwa seluruh instrumen 


\begin{tabular}{|c|c|c|c|}
\hline $\mathrm{X} 2$ & 0.985 & $\begin{array}{l}1.01 \\
5\end{array}$ & $\begin{array}{l}\text { Bebas } \\
\text { Multikolinearita } \\
\text { s }\end{array}$ \\
\hline Goal & 0.985 & $\begin{array}{l}1.01 \\
5\end{array}$ & $\begin{array}{l}\text { Bebas } \\
\text { Multikolinearita } \\
\text { s }\end{array}$ \\
\hline $\mathrm{X} 1$ & 0.985 & $\begin{array}{l}1.01 \\
5\end{array}$ & $\begin{array}{l}\text { Bebas } \\
\text { Multikolinearita } \\
\text { s }\end{array}$ \\
\hline $\mathrm{X} 2$ & 0.985 & $\begin{array}{l}1.01 \\
5\end{array}$ & $\begin{array}{l}\text { Bebas } \\
\text { Multikolinearita } \\
\text { s }\end{array}$ \\
\hline $\begin{array}{l}\text { Performanc } \\
\text { e }\end{array}$ & 0.985 & $\begin{array}{l}1.01 \\
5\end{array}$ & $\begin{array}{l}\text { Bebas } \\
\text { Multikolinearita } \\
\text { s }\end{array}$ \\
\hline $\mathrm{X} 1$ & 0.985 & $\begin{array}{l}1.01 \\
5\end{array}$ & $\begin{array}{l}\text { Bebas } \\
\text { Multikolinearita } \\
\text { s }\end{array}$ \\
\hline $\mathrm{X} 2$ & 0.985 & $\begin{array}{l}1.01 \\
5\end{array}$ & $\begin{array}{l}\text { Bebas } \\
\text { Multikolinearita } \\
\text { s }\end{array}$ \\
\hline
\end{tabular}

Artinya nilai perhitungan nilai variance inflation factor (VIF) menunjukan tidak ada satu variabel independen yang meiliki nilai $\mathrm{VIF}<0,1$ dan berarti tidak ada satu variabel independen yang memiliki nilai VIF > 10 yang berarti tidak ada multikolinearitas antar variabel independen dalam model regresi.

\section{Asumsi Fit Model}

Uji Hosmer and Lemeshow

Tabel 8. Uji Hosmer dan Lemeshow 1

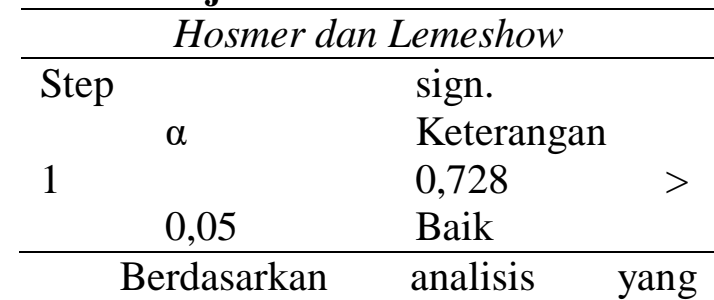

dilakukan terhadap variabel dependen Self-Efficacy, hasilnya menunjukan bahwa model regresi logistik ini sudah memenuhi asumsi kelayakan model, hal ini dapat dilihat dari nilai $0,728>$ 0,05 .
Tabel 9. Uji Hosmer dan Lemeshow 2

\begin{tabular}{llll}
\hline \multicolumn{4}{c}{ Hosmer dan Lemeshow } \\
\hline Step & \multicolumn{3}{c}{ sign. } \\
& $\alpha$ & Keterangan & \\
1 & & 0,721 & \\
& & 0,05 & Baik \\
& Berdasarkan & analisis yang
\end{tabular}

dilakukan terhadap varialab dependen Goal, hasilnya menunjukan bahwa model regresi logistik ini sudah memenuhi asumsi kelayakan model, hal ini dapat dilihat dari nilai $0,721>0,05$.

Tabel 10. Uji Hosmer dan Lemeshow

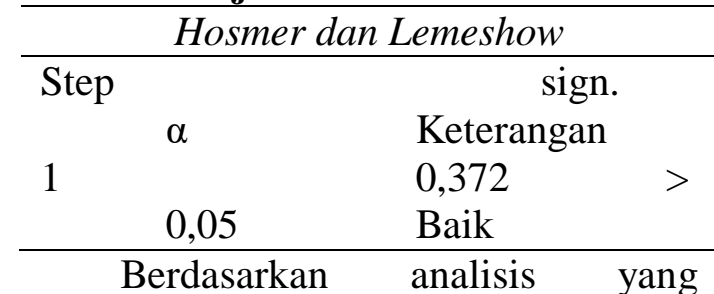
dilakukan terhadap variabel dependen Performance, hasilnya menunjukan bahwa model regresi asumsi logistik ini sudah memenuhi asumsi kelayakan model, hal ini dapat dilihat dari nilai $0,372>0,05$.

\section{Uji Likelihood Fit Model}

Tabel 11 Uji Likelihood 1

\begin{tabular}{lcccc}
\hline \multicolumn{5}{c}{ Likelihood fit model } \\
\hline Step & -2 LogLikelihood & Step & -2 LogLikelihood & Ket \\
0 & 112,454 & 1 & 105,15 & Baik \\
\hline
\end{tabular}

Berdasarkan analisis yang sudah dilakukan terhadap variabel dependen Self-Efficacy, hasilnya menunjukan bahwa model regresi logistik sudah memenuhi asumsi kelayakan model, hal ini dapat dilihat dari adanya penurunan nilai -2 Log Likelihood pada model awal sebesar 112,454 dengan angka -2 Log Likelihood pada model akhir sebesar 105,155 .

Tabel 12 Uji Likelihood 2

\begin{tabular}{|c|c|c|c|}
\hline \multicolumn{4}{|c|}{ Likelihood fit model } \\
\hline $\begin{array}{l}\text { Step } \\
0\end{array}$ & $\begin{array}{l}-2 \text { LogLikelihood } \\
110,534\end{array}$ & $\begin{array}{lc}\text { Step } & -2 \text { LogLikelihood } \\
1 & 61,642\end{array}$ & $\begin{array}{l}\text { Ket. } \\
\text { Baik }\end{array}$ \\
\hline
\end{tabular}

dilakukan terhadap variabel dependen Goal, hasilnya menunjukan bahwa model regresi logistik sudah memenuhi asumsi kelayakan model, hal ini dapat 
dilihat dari adanya penurunan nilai -2 Log Likelihood pada model awal sebesar 110,534 dengan angka -2 Log Likelihood pada model akhir sebesar 61,642 .

Tabel 13 Uji Likelihood 3

\begin{tabular}{|c|c|c|c|c|}
\hline \multicolumn{5}{|c|}{ Likelihood fit model } \\
\hline Step & -2 LogLikelihood & Step & -2LogLikelihood & Ket. \\
\hline 0 & 112,454 & 1 & 89,348 & Baik \\
\hline
\end{tabular}

Berdasarkan analisis yang sudah dilakukan terhadap variabel dependen Performance, hasilnya menunjukan bahwa model regresi logistik sudah memenuhi asumsi kelayakan model, hal ini dapat dilihat dari adanya penurunan nilai -2 Log Likelihood pada model awal sebesar 112,454 dengan angka -2 Log Likelihood pada model akhir sebesar 89,348 .

\section{Analisis Regresi Logistik}

Tabel 14 Analisis Regresi Logistik 1

\begin{tabular}{lccccc}
\hline $\begin{array}{l}\text { Variabel } \\
\text { independer }\end{array}$ & $\begin{array}{c}\text { Exp } \\
(\mathrm{B})\end{array}$ & Sign. & & $\alpha$ & Keterangan \\
\hline (Constant) & 0,553 & 0,308 & & & \\
\hline SLGO & - & 0,986 & $>$ & 0,05 & $\begin{array}{c}\text { Tidak } \\
\text { signifikan }\end{array}$ \\
& 0,009 & & & & Signifikan \\
\hline SPGO & - & 0,009 & $<$ & 0,05 & Sign \\
& 1,268 & & & & \\
\hline
\end{tabular}

Berdasarkan koefisien regresi logistik, maka persamaan regresi yang dapat dibentuk adalah :

$$
\begin{gathered}
\operatorname{Ln}\left(\frac{P}{1-P}\right)=0,553-0,009 \text { SLGO - } \\
\text { 1,269 SPGO }
\end{gathered}
$$

1. Pada model regresi kostantan ini memiliki nilai 0,553 yang berarti jika variabel Independen dalam model diasumsikan sama dengan nol maka kemampuan Self-Efficacy sebesar 0,553 .

2. Variabel SLGO

Nilai koefisien regresi ini menunjukan bahwa jika SLGO meningkat sebesar satu satuan dan variabel lain konstan, maka kemampuan Self-Efficacy menurun sebesar -0,009 satuan.

3. Variabel SPGO

Nilai koefisien regresi ini menunjukan bahwa jika SLGO meningkat sebesar satu satuan dan variabel lain konstan, maka kemampuan Self-Efficacy menurun sebesar -1,268 satuan.

Tabel 15 Analisis Regresi Logistik 2

\begin{tabular}{lccccc}
\hline $\begin{array}{l}\text { Variabel } \\
\text { independer }\end{array}$ & $\begin{array}{c}\text { Exp } \\
(\mathrm{B})\end{array}$ & Sign. & $\alpha$ & Keterangan \\
\hline (Constant) & 1,010 & 0,148 & & & \\
\hline SLGO & 1,488 & 0,108 & $>0,05$ & $\begin{array}{c}\text { Tidak } \\
\text { signifikan }\end{array}$ \\
\hline SPGO & - & 0,000 & $<$ & 0,05 & Signifikan \\
& 4,178 & & & & \\
\hline
\end{tabular}

Berdasarkan koefisien regresi logistik, maka persamaan regresi yang dapat dibentuk adalah :

$$
\begin{gathered}
\operatorname{Ln}\left(\frac{P}{1-P}\right)=1,010+1,488 \text { SLGO - } \\
4,178 \text { SPGO }
\end{gathered}
$$

1. Pada model regresi kostantan ini memiliki nilai 1,010 yang berarti jika variabel Independen dalam model diasumsikan sama dengan nol maka kemampuan Goal sebesar 1,010.

Variabel SLGO

Nilai koefisien regresi ini menunjukan bahwa jika SLGO meningkat sebesar satu satuan dan variabel lain konstan, maka kemampuan Goal meningkat sebesar 1,448 satuan.

3. Variabel SPGO

Nilai koefisien regresi ini menunjukan bahwa jika SLGO meningkat sebesar satu satuan dan variabel lain konstan, maka kemampuan Goal menurun sebesar $-4,178$ satuan.

Tabel 16 Analisis Regresi Logistik 3

\begin{tabular}{lccccc}
\hline $\begin{array}{l}\text { Variabel } \\
\text { independer }\end{array}$ & $\operatorname{Exp}(\mathrm{B})$ & Sign. & $\alpha$ & Keterangan \\
\hline (Constant) & 1,936 & 0,014 & & & \\
\hline SLGO & $-3,064$ & 0,000 & $<$ & 0,05 & Signifikan \\
\hline SPGO & 0,421 & 0,454 & $>$ & 0,05 & Tidak signifikan \\
\hline
\end{tabular}

Berdasarkan koefisien regresi logistik, maka persamaan regressi yang dapat dibentuk adalah :

$$
\begin{gathered}
\operatorname{Ln}\left(\frac{P}{1-P}\right)=1,936-3,064 \text { SLGO + } \\
0,421 \text { SPGO }
\end{gathered}
$$


1. Pada model regresi kostantan ini memiliki nilai 1,936 yang berarti jika variabel Independen dalam model diasumsikan sama dengan nol maka kemampuan Perforance sebesar 1,936.

2. Variabel SLGO

Nilai koefisien regresi ini menunjukan bahwa jika SLGO meningkat sebesar satu satuan dan variabel lain konstan, maka kemampuan Perforance menurun sebesar 3,064 satuan.

3. Variabel SPGO

Nilai koefisien regresi ini menunjukan bahwa jika SLGO meningkat sebesar satu satuan dan variabel lain konstan, maka kemampuan Perforance meningkat sebesar 0,421 satuan.

\section{Uji Hipotesis}

Tabel 17 Negelkerke R Square

\begin{tabular}{|c|c|c|}
\hline \multicolumn{3}{|c|}{ Nagelkerke $R$ Square } \\
\hline Self-Efficac & Goal & \\
\hline 0,114 & $\begin{array}{l}c e \\
0,607\end{array}$ & 0,329 \\
\hline
\end{tabular}

Artinya bahwa Self-Efficacy, Goal dan Performance yang memiliki kemampuan yang diasumsikan adalah sebesar $11,4 \%, 60,7 \%$ dan $32,9 \%$ dan sisanya $88,6 \%, \quad 39,3 \%$ dan 67,1 dijelaskan oleh variabel lain diluar variabel penelitian.

Tabel 18 Uji Omnimbus Test

\begin{tabular}{|c|c|c|}
\hline & Dmnimbus Test & \\
\hline Self-Efficacy & Goal & \\
\hline $\begin{array}{l}\text { Performance } \\
7,299\end{array}$ & 48,892 & 23,106 \\
\hline
\end{tabular}

model logistik diketahui berturut-turut adalah sebesar 7,299, 48,892 dan $23,106>5,991$ dengan tingkat signifikansi sama dengan nol $(=0)$, maka Ho ditolak dan Ha diterima, yang berarti secara serentak variabel SLGO dan SPGO akan mengindikasikan kemungkinan berpengaruh terhadap Self-Efficacy, Goal dan Performance.

\section{Uji Wald Test}

Tabel 19 Uji Omnimbus Test Omnimbus Test

\begin{tabular}{llll}
\hline Self-Efficacy & $\mathrm{B}$ & $\alpha$ & sign. \\
X1 & $-0,009$ & 0,05 & $<0,986$ \\
X2 & $-1,268$ & 0,05 & $>0,009$ \\
Goal & $\mathrm{B}$ & $\alpha$ & sign. \\
X1 & 1,488 & 0,05 & $<0,108$ \\
X2 & $-4,178$ & 0,05 & $>0,000$ \\
Performance & $\mathrm{B}$ & $\alpha$ & sign. \\
X1 & $-3,064$ & 0,05 & $>0,000$ \\
X2 & $-0,421$ & 0,05 & $<0,45$ \\
\hline
\end{tabular}

1. Variabel SLGO memiliki koefisien regresi sebesar -0,009 dengan tingkat signifikansi sebesar 0,986. Karena nilai signifikansinya lebih besar dari 0,05 atau $5 \%$, maka dapat dinyatakan dengan variabel SLGO tidak berpengaruh signifikan terhadap SelfEfficacy (Y1). Sehingga hipotesis altenatif yang menyatakan bahwa variabel SLGO mempunyai pengaruh terhadap Self-Efficacy (Y1) tidak terbukti kebenarannya atau $\mathrm{Ha}$ ditolak.

2. Variabel SPGO memiliki koefisien regresi sebesar -1,268 dengan tingkat signifikansi sebesar 0,009. Karena nilai signifikansinya lebih kecil dari 0,05 atau $5 \%$, maka dapat dinyatakan dengan variabel SPGO berpengaruh signifikan terhadap Self-Efficacy (Y1). Sehingga hipotesis altenatif yang menyatakan bahwa variabel SPGO mempunyai pengaruh terhadap Self-Efficacy (Y1) terbukti kebenarannya atau Ha diterima.

3. Variabel SLGO memiliki koefisien regresi sebesar 1,488 dengan tingkat signifikansi sebesar 0,108. Karena nilai signifikansinya lebih besar dari 0,05 atau 5\%, maka dapat dinyatakan dengan variabel SLGO tidak berpengaruh signifikan terhadap Goal (Y2). Sehingga hipotesis altenatif yang menyatakan bahwa variabel SLGO mempunyai pengaruh terhadap Goal (Y2) tidak terbukti kebenarannya atau Ha ditolak.

4. Variabel SPGO memiliki koefisien regresi sebesar -4,178 dengan tingkat 
signifikansi sebesar 0,000. Karena nilai signifikansinya lebih kecil dari 0,05 atau $5 \%$, maka dapat dinyatakan dengan variabel SPGO berpengaruh signifikan terhadap Goal (Y2). Sehingga hipotesis altenatif yang menyatakan bahwa variabel SPGO mempunyai pengaruh terhadap Goal (Y2) terbukti kebenarannya atau $\mathrm{Ha}$ diterima.

5. Variabel SLGO memiliki koefisien regresi sebesar -3,064 dengan tingkat signifikansi sebesar 0,000. Karena nilai signifikansinya lebih kecil dari 0,05 atau $5 \%$, maka dapat dinyatakan dengan variabel SLGO berpengaruh signifikan terhadap Performance (Y3). Sehingga hipotesis altenatif yang menyatakan bahwa variabel SLGO mempunyai pengaruh terhadap Performance (Y3) terbukti kebenarannya atau Ha diterima.

6. Variabel SPGO memiliki koefisien regresi sebesar -0,421 dengan tingkat signifikansi sebesar 0,454. Karena nilai signifikansinya lebih besar dari 0,05 atau $5 \%$, maka dapat dinyatakan dengan variabel SPGO tidak berpengaruh signifikan terhadap Performance (Y3). Sehingga hipotesis altenatif yang menyatakan bahwa variabel SPGO mempunyai pengaruh terhadap Performance (Y3) tidak terbukti kebenarannya atau $\mathrm{Ha}$ ditolak.

1. Pengaruh State Learning Goal Orientation (SLGO) terhadap SelfEfficacy

Hasil dari analisis data yang telah diolah menunjukan bahwa State Learning Goal Orientation (SLGO) tidak berpengaruh terhadap SelfEfficacy. Dapat dilihat dari hasil tabel 4.15 dan tabel 4.20 bahwa tidak terjadi pengaruh antara State Learning Goal Orientation (SLGO) terhadap SelfEfficacy dimana nilai tersebut lebih besar dari 0,05 atau 5\%. Dengan demikian hipotesis 1 (H1) ditolak. Maka dapat disimpulkan bahwa tidak ada pengaruh signifikan State Learning Goal Orientation (SLGO) terhadap SelfEfficacy Mahasiswa Prodi Akuntansi di Kabupaten Jember.

Hasil ini menunjukan bahwa tingkat Learning Goal Orientation (LGO) seseorang tidak dapat mempengaruhi tingkat kepercayaan dirinya. Mahasiswa dengan LGO yang lemah cenderung tidak suka dengan tantangan dan tidak menerapkan tujuan yang tinggi serta takut dengan kegagalan pencapaian tujuan. Hasil ini berbanding terbalik dengan penilitian hasi ldari Ilyas, dkk (2007). Jadi saat LGO seseorang mahasisiwa rendah, kepercayaan dirinya pun akan semakin rendah sehingga tujuan yang besar akan menghasilkan kinerja yang buruk.

Hal ini berarti tidak konsisten dengan hasil penemuan/penelitian terdahulu yang dilakukan oleh Ilyas, Herliansyah dam Muslim (2007).

2. Pengaruh State Learning Goal Orientation (SLGO) terhadap Goal

Hasil dari analisis data yang telah diolah menunjukan bahwa State Learning Goal Orientation (SLGO) tidak berpengaruh terhadap Goal. Dapat dilihat dari hasil tabel 4.15 dan tabel 4.20 bahwa tidak terjadi pengaruh antara State Learning Goal Orientation (SLGO) terhadap Goal dimana nilai tersebut lebih besar dari 0,05 atau 5\%. Dengan demikian hipotesis 2 (H2) ditolak. Maka dapat disimpulkan bahwa tidak ada pengaruh signifikan State Learning Goal Orientation (SLGO) terhadap Goal Mahasiswa Prodi Akuntansi di Kabupaten Jember.

Hal ini menunjukan bahwa mahasiswa enggan untuk mempelajari keahlian dan ilmu-ilmu yang baru. Karakteristik mahasiswa seperti ini adalah mahasiswa yang memiliki daya tahan yang lemah ketika dihadapkan 
dengan eksperimen yang baru atau dihadapkan pada suatu masalah yang baru. Tidak ingin mencoba hal-hal yang baru untuk memecahkan permasalahan serta tantangan yang dihadapi. Learning Goal Orientation (LGO) tidak dapat memprediksi keberhasilan suatu prestasi akademis yang lebih baik dibandingkan dengan perkiraan dari kepribadian dan kecerdasan seseorang.

Hal ini berarti tidak konsisten dengan hasil penemuan/penelitian terdahulu yang dilakukan olah Ilyas, Herliansyah dan Muslim (2007).

3. Pengaruh State Learning Goal Orientation (SLGO) terhadap Performance

Hasil dari analisis data yang telah diolah menunjukan bahwa State Learning Goal Orientation (SLGO) berpengaruh terhadap Perforance. Dapat dilihat dari hasil tabel 4.15 dan tabel 4.20 terjadi pengaruh antara State Learning Goal Orientation (SLGO) terhdap Perforance, dimana nilai tersebut lebih kecil dari 0,05 atau 5\%. Dengan demikian hipotesis 3 (H3) diterima. Maka dapat disimpulkan bahwa ada pengaruh signifikan State Learning Goal Orientation (SLGO) terhadap Perforance Mahasiswa Prodi Akuntansi di Kabupaten Jember.

Ketika seseorang mahasiswa mengejar Learning Goal Orientation (LGO) maka seseorang mahasiswa tersebut mempunyai tujuan atau kinerja untuk mengembangkan pontensi yang dimilikinya dengan cara memperoleh teori-teori yang didapat dan pengetahuan-pengetahuan baru. Orang tipe LGO ini memalukan berbagai aktifitas terhadap kinerjanya agara dapat meningkatkan pengetahuan dan wawasan yang lebih dari proses kinerjanya, serta sebuah upaya yang dipandang sebagai hal yang baik atau positif untuk mencapai kinerja setiap individu.
Hal ini berarti konsisten dengan hasil penemuan atau penelitian terdahulu yang dilakukan oleh Ilyas, Herliansyah dan Muslim (2007).

4. Pengaruh State Performance Goal Orientation (SPGO) terhadap SelfEfficacy

Hasil dari analisis data yang telah diolah menunjukan bahwa State Performance Goal Orientation (SPGO) berpengaruh terhadap Self-Efficacy. Dapat dilihat dari hasil Tabel 4.15 dan Tabel 4.20 terjadi pengaruh antara State Performance Goal Orientation (SPGO) terhdap Self-Efficacy dimana nilai tersebut lebih kecil dari 0,05 atau 5\%. Dengan demikian hipotesis 4 (H4) diterima. Maka dapat disimpulkan bahwa ada pengaruh signifikan State Performance Goal Orientation (SPGO) terhadap Self-Efficacy Mahasiswa Prodi Akuntansi di Kabupaten Jember.

Hasil penelitian ini menunjukan bahwa tingkat Performance Goal Orientation (PGO) seseorang dapat mempengaruhi tingkat kepercayaan dirinya. Hal ini dapat disebabkan oleh Mahasiswa dengan PGO yang tinggi cenderung tidak suka dengan hasil akhir pada proses perkuliahan dan model PGO ini merupakan keyakinan yang dimiliki setiap individu untuk menuntaskan atau menyelesaikan sebuah tugas yang diberikan dengan tingkat kesulitan tinggi yang dipengaruhi dari tindakan personalitas terhadap pencapaian tujuan, serta bertujuan untuk melihat kecakapan individu yang diacu dari persepsi kemampuan dalam menerapkan dan mengatur suatu tindakan. Jadi dapat diartikan bahwa pengaruh Self-Efficacy merupakan kepercayaan individu terhadap kemapuannya dalam mengatur dan melaksanakan sesuatu dengan suatu rangkaian tindakan dalam mencapai hasil yang ditetapkan (Pradiantie, 2012). 
Hal ini berarti konsisten dengan hasil penemuan atau penelitian terdahulu yang dilakukan oleh Ilyas, Herliansyah dam Muslim (2007).

5. Pengaruh State Performance Goal Orientation (SPGO) terhadap Goal

Hasil dari analisis data yang telah diolah menunjukan bahwa State Performance Goal Orientation (SPGO) berpengaruh terhadap Goal. Dapat dilihat dari hasil tabel 4.15 dan tabel 4.20 terjadi pengaruh antara State Performance Goal Orientation (SPGO) terhdap Self-Efficacy dimana nilai tersebut lebih kecil dari 0,05 atau 5\%. Dengan demikian hipotesis $5(\mathrm{H})$ diterima. Maka dapat disimpulkan bahwa ada pengaruh signifikan State Performance Goal Orientation (SPGO) terhadap Goal Mahasiswa Prodi Akuntansi di Kabupaten Jember.

Hasil penelitian ini hanya memfokuskan pada kemampuan dasi aspek keunggulan dan kelebihan yang dimiliki lebih dari orang lain. Suatu tujuan yang dimiliki mahasiswa ini merupakan suatu pertanyaan yang sangat penting tentang bagaimana keadaan yang ingin dicapai dalam waktu yang telah ditentukan bukan hanya mengejar nilai akhirnya saja. Tujuan ini ditetapkan sebagai dasar suatu pengakuan untuk menilai pencapaian tujuan dan juga sebagai penciptaan proses pengendalian agar individu tidak dikucilkan oleh orang lain.

Hal ini berarti konsisten dengan hasil penemuan atau penelitian terdahulu yang dilakukan oleh Ilyas, Herliansyah dan Muslim (2007).

6. Pengaruh State Performance Goal Orientation (SPGO) terhadap Performance

Hasil dari analisis data yang telah diolah menunjukan bahwa State Performance Goal Orientation (SPGO) tidak berpengaruh terhadap
Performance. Dapat dilihat dari hasil tabel 4.15 dan tabel 4.20 terjadi pengaruh antara State Performance Goal Orientation (SPGO) terhadap Performance dimana nilai tersebut lebih besar dari 0,05 atau 5\%. Dengan demikian hipotesis 6 (H6) ditolak. Maka dapat disimpulkan bahwa tidak ada pengaruh signifikan State Performance Goal Orientation (SPGO) terhadap Performance Mahasiswa Prodi Akuntansi di Kabupaten Jember.

Hasil penelitian ini bahwa Performance Goal Orientation (PGO) terhadap kinerja mahasiswa perlu ditingkatkan kembali karena dengan adanya peningkatan baik dari segi kualitas maupun kuantitas maka mahahsiswa dapat dengan luluasa untuk meningkatkan kembali kinerjanya terhadap hasil pembelajaran atau proses pembelajaran.

Hal ini berarti tidak konsisten dengan hasil penemuan atau penelitian terdahulu yang dilakukan oleh Ilyas, Heliansyah dan Muslim (2007).

\section{PENUTUP}

\section{Kesimpulan}

Berdasarkan dari hasil penelitian, oleh data menggunakan SPSS dan analisis yang telah dijelaskan pada bab sebelumnya, maka dapat ditarik disimpulkan sebagai berikut :

1. Variabel State Learning Goal Orientation (SLGO) memiliki koefisien regresi sebesar $-0,009$ dengan tingkat signifikan 0,986. Karena nilai signifikansinya lebih besar dari 0,05 atau 5\%, maka dapat dinyatakan bahwa variabel State Learning Goal Orientation (SLGO) tidak berpengaruh signifikan terhadap Self-Efficacy (Y1). Sehingga, hipotesis alternatif yang menyatakan bahwa variabel State Learning Goal Orientation (SLGO) terhadap Self-Efficacy (Y1) 
tidak terbukti kebenarannya atau H1 ditolak.

2. Variabel State Learning Goal Orientation (SLGO) memiliki koefisien regresi sebesar 1,488 dengan tingkat signifikan 0,108 . Karena nilai signifikansinya lebih besar dari 0,05 atau 5\%, maka dapat dinyatakan bahwa variabel State Learning Goal Orientation (SLGO) tidak berpengaruh signifikan terhadap Goal (Y2). Sehingga, hipotesis alternatif yang menyatakan bahwa variabel State Learning Goal Orientation (SLGO) terhadap Goal (Y2) tidak terbukti kebenarannya atau $\mathrm{H} 2$ ditolak.

3. Variabel State Learning Goal Orientation (SLGO) memiliki koefisien regresi sebesar $-3,064$ dengan tingkat signifikan 0,000 . Karena nilai signifikansinya lebih kecil dari 0,05 atau 5\%, maka dapat dinyatakan bahwa variabel State Learning Goal Orientation (SLGO) berpengaruh signifikan terhadap Perforance (Y3). Sehingga, hipotesis alternatif yang menyatakan bahwa variabel State Learning Goal Orientation (SLGO) terhadap Perforance (Y3) terbukti kebenarannya atau $\mathrm{H} 3$ diterima.

4. Variabel State Performance Goal Orientation (SPGO) memiliki koefisien regresi sebesar $-1,268$ dengan tingkat signifikan 0,009. Karena nilai signifikansinya lebih kecil dari 0,05 atau 5\%, maka dapat dinyatakan bahwa variabel State Performance Goal Orientation (SPGO) berpengaruh signifikan terhadap Self-Efficacy (Y1). Sehingga, hipotesis alternatif yang menyatakan bahwa variabel State Performance Goal Orientation (SPGO) terhadap Self-Efficacy (Y1) terbukti kebenarannya atau $\mathrm{H} 4$ diterima.
5. Variabel State Performance Goal Orientation (SPGO) memiliki koefisien regresi sebesar $-4,178$ dengan tingkat signifikan 0,000 . Karena nilai signifikansinya lebih kecil dari 0,05 atau 5\%, maka dapat dinyatakan bahwa variabel State Performance Goal Orientation (SPGO) berpengaruh signifikan terhadap Goal (Y2). Sehingga, hipotesis alternatif yang menyatakan bahwa variabel State Performance Goal Orientation (SPGO) terhadap Goal (Y2) terbukti kebenarannya atau H5 diterima.

6. Variabel State Performance Goal Orientation (SPGO) memiliki koefisien regresi sebesar 0,421 dengan tingkat signifikan 0,454. Karena nilai signifikansinya lebih besar dari 0,05 atau 5\%, maka dapat dinyatakan bahwa variabel State Performance Goal Orientation (SPGO) tidak berpengaruh signifikan terhadap Performance (Y3). Sehingga, hipotesis alternatif yang menyatakan bahwa variabel State Performance Goal Orientation (SPGO) terhadap Performance (Y3) tidak terbukti kebenarannya atau H6 ditolak.

\section{Saran}

1. Bagi Peneliti Berikutnya

Peneliti merekomendasikan atau menyarankan untuk penelitian yang akan datang adalah memperluas cakupan responden Prodi Akuntansi di Kabupaten Jember. Peneliti juga bisa melakukan penelitian di seluruh Prodi Akuntansi di Kabupaten Jember lainnya.

2. Bagi Universitas

Universitas diharapkan sering mensosialisasikan mengenai orientasi tujuan dan cara 
penyelesaiaannya tehadap dua buah pola perilaku yaitu Learning Goal Orientation (LGO) dan Performance Goal Orientation (PGO) agar lebih banyak lagi cakupan yang dibuat sampel selain Prodi Akuntansi, sehingga penelitian akan lebih baik lagi kedepannya.

\section{DAFTAR PUSTAKA}

Ames, C., \& Archer, J. (1988). Achievement Goals in The Classroom: Students' Learning Strategies and Motivation Processes. Journal of Educational Psychology, 80, 260-267.

Amsi A.,F. (2007). Pengaruh Kecerdasan Emosional dan Kecerdasan Spiritual terhadap Tingkat Pemahaman Akuntansi. Skripsi Fakultas Ekonomi. Penerbit Universitas Islam Sultan Agung. Semarang (tidak dipublikasikan).

Arikunto, S. (2002). Prosedur Penelitian Suatu Pendekatan Praktek. Cetakan Ke duabelas, Edisi Revisi V, Jakarta: Penerbit Rineka Cipta.

Beaubien, J. M.,\& Payne, S. C. (1999). Individual Goal Orientation as a Predictor of Job and Academic Performance: A Meta-Analytic Review and Integration. Paper presented at the 14th annual conference of the Society for Industrial and Organizational Psychology, Atlanta.

Boyle, K. A.,\& Klimoski, R. J. (1995) Toward an Understanding of Goal Orientation in A Training Context. Paper presented at the 10th annual meeting of the Society for Industrial and Organizational Psychology, Orlando, FL.
Butler, R. (1987). Task-Involving and Ego-Involving Properties of Evaluation: Effects of Different Feedback Conditions on Motivational Perceptions, Interest, and Performance. Journal of Educational Psychology, 79, 474482.

Butler, R. (1993). Effects of Task- and Ego-Achievement Goals on Information Seeking During Task Engagement. Journal of Personality and Social Psychology, 65, 18-31.

Button, S. B., Mathieu, J. E., \& Zajac, D. M. (1996). Goal Orientation in Organizational Research: A Conceptual and Empirical Foundation. Organizational Behavior and Human Decision Processes, 67, 26-48.

Chen, G., Gully, S. M., Whiteman, J., \& Kilcullen, R. N. (2000). Examination of Relationships Among Trait-Like Individual Differences, State-Like Individual Differences and Learning Performance. Journal of Applied Psychology, 85, 835-847.

Desmita. (2010). Psikologi Perkembangan Peserta Didik. Bandung: Penerbit Rosda

Donovan, J. J. \& Williams, K. J. (1999). Contextual, Dispositional and Cognitive Influences on Goal Revision. Paper presented at the 1999 annual conference of the Society for Industrial and Organizational Psychology, Atlanta, GA.

Dweck, C. S., \& Leggett, E. L. 1988. A Social-Cognitive Approach to Motivation and Personality. Psychological Review, 95, 256273. 
Elliot, E. S., \& Church, M. A. (1997). A Hierarchical Model of Approach and Avoidance Achievement Motivation. Journal of Personality and Social Psychology, 72, 218-232.

Ghozali, I. (2001). Aplikasi Analisis Multivariate Dengan Program SPSS. Badan Penerbit Universitas Diponegoro: Semarang

Gujarati, D. (1997). Ekonometrika Dasar. Alih Bahasa Sumarno Zain. Jakarta: Penerbit Erlangga

Ilyas, H \& Muskim. (2007). Peran Pernyataan Orientasi (State Goal Orientation) Dalam Pengajaran Dikelas Terhadap Proses Pencapaian Kinerja Mahasiswa Akuntansi Di Perguruan Tinggi. Simposium Nasional Akuntansi $\mathrm{X}$ : Makasar

Johnson, D.S., Beauregard, R.S., Hoover, P.B. \& Schmidt, A.M. (2000). Goal Orientation and Task Demand Effects on Motivation, Affect and Performance. Journal of Applied Psychology, 85(5), 724-738.

Lee, C. L., \& Bobko, P. (1994). SelfEfficacy Beliefs: Comparison of five measures. Journal of Applied Psychology, 79, 364-369.

Locke, E. A., \& Latham, G. P. (1990). A theory of Goal Setting and Task Performance. Engelwood Cliffs, NJ: Prentice Hall.

Mangos, P. M.,\& Steele-Johnson, D. (2001). The Role of Subjective Task Complexity in Goal Orientation, Self-Efficacy and Performance Relations. Human Performance, 41, 169-186.

Martocchio, J. J. (1994). Effects of Conceptions of Ability on Anxiety, Self-Efficacy and Learning in Training. Journal of Applied Psychology, 79, 819-825.
McClelland, D. C. (1965). Toward a Theory of Motive Acquisition. American Psychologist, 20, 321333.

Nadhiroh, S.,A. (2010). Pengaruh Kompleksitas Tugas, Orientasi Tujuan dan Self-Efficacy terhadap Auditor dalam Pembuatan Audit Judgment (Studi pada Kantor Akuntan Publik di Semarang). Skripsi Program Sarjana Fakultas Ekonomi UNDIP. Semarang.

Nur, I \& Bambang, S. (2009). Metodologi Penelitian Bisnis untuk Akuntansi \& Manajemen. Yogyakarta: Penerbit BPFE

Payne, S. C., Youngcourt, S. S. \& Beaubien, J. M. (2007). A MetaAnalytic Examination of The Goal Orientation Nomological Net. Journal of Applied Psychology, 92: 128-150.

Phillips, J. M., \& Gully, S.M. (1997). Role of Goal Orientation, Ability, Need for Achievement and Locus of Control in The Self-Efficacy and Goal-Setting Process. Journal of Applied Psychology, 82, 792802.

Porath, C. L. \& Bateman, T. S. (2006). Self-Regulation: From Goal Orientation to Job Performance. Journal of Applied Psychology, 91: 185-192.

Rono, M.K. (2012). Hubungan Antara Goal Orientation dan Prestasi Akademis pada Mahasiswa Fakultas Psikologi Universitas Indonesia. Skripsi Program Sarjana Fakultas Psikologi UI: Depok.

Singarimbun, M \& Sofian.,E. (1989). Metode Penelitian Survey. LP3ES: Jakarta. 
Steele-Johnson, D., Beauregard, R. S., Hoover, P. B., \& Schmidt, A. M. (2000). Goal Orientation and Task Demand Effects on Motivation, Affect and Performance. Journal of Applied Psychology, 85, 724-738.

Sudarmanto, R \& Gunawan. (2005). Analisis Regresi Linear Ganda dengan SPSS. Edisi Pertama. Penerbit Graha Ilmu: Yogyakarta

Sugiyono. (2014). Metode Penelitian Pendidikan Pendekatan Kuantitatif, Kualitatif dan R\&D. Penerbit Alfabeta: Bandung

Umar, H. (2000). Research Methods in Finance and Banking. Jakarta: Penerbit Gramedia Pustaka Utama:

VandeWalle, D., Cron, W. L., \& Slocum, J. W. (2001). The Role of Goal Orientation Following Performance Feedback. Journal of Applied Psychology, 86, 629-640.

Verbeeten, F.,H. (2006). Performance Management Practices in Public Sector Organizations, Accounting, Auditing \& Accountability Journal, Vol. 21 No.3, h. 427 454.

Zweig, D. \& Webster, J. (2004). What are We Measuring? An Examination of The Relationships Between The Big-Five Personality Traits, Goal Orientation and Performance Intentions. Personality and Individual Differences, 36: 1693-1708. 